\title{
Update of Diagnostic Evaluation of Craniosynostosis with a Focus on Pediatric Systematic Evaluation and Genetic Studies
}

\author{
Su-Kyeong Hwang, M.D., Ki-Su Park, M.D., ${ }^{2}$ Seong-Hyun Park, M.D., ${ }^{2}$ Sung Kyoo Hwang, M.D. ${ }^{2}$ \\ Departments of Pediatrics, ${ }^{1}$ Neurosurgery, ${ }^{2}$ Kyungpook National University Hospital, Daegu, Korea
}

\begin{abstract}
Most craniosynostoses are sporadic, but may have an underlying genetic basis. Secondary and syndromic craniosynostosis accompanies various systemic diseases or associated anomalies. Early detection of an associated disease may facilitate the interdisciplinary management of patients and improve outcomes. For that reason, systematic evaluation of craniosynostosis is mandatory. The authors reviewed systematic evaluation of craniosynostosis with an emphasis on genetic analysis.
\end{abstract}

Key Words : Craniosynostosis · Diagnosis · Genetic.

\section{INTRODUCTION}

Craniosynostosis is premature fusion of one or more cranial sutures, which is usually encountered early in life. This relatively common disorder of the skull affects between 1 in 2100 to 2500 children $^{1,11)}$. Pediatricians are usually the first physicians who encounter the craniosynostosis patients. Most cases are sporadic, but may have an underlying genetic basis. Skull deformities have a wide range of etiologies from positional plagiocephaly to complex genetic syndromes. Craniosynostosis can be divided into primary, secondary, syndromic or nonsyndromic; more than $85 \%$ of patients have nonsyndromic craniosynostosis ${ }^{2)}$. Primary single-suture synostosis is relatively easy to diagnose because the main symptom is skull deformity, which is typical according to the fused suture. Multiple suture synostosis is less common than single suture, accounting for $\sim 15 \%$ of cases. The intracranial pressure is usually normal in primary craniosynostosis, although $\sim 20 \%$ of single-suture synostosis patients have high intracranial pressure ${ }^{18,21)}$. Brain damage in cases of singlesuture synostosis is usually mild but requires prolonged monitoring $^{7)}$. Increased intracranial pressure and brain damage are more common in secondary or syndromic craniosynostosis. Secondary or syndromic craniosynostosis is more difficult to diagnose despite recent radiological advancements. Syndromic cra- niosynostosis should be diagnosed as early as possible to facilitate interdisciplinary management, improve outcomes and provide genetic counseling for parents. In this regard, the authors reviewed diagnostic evaluation with a focus on pediatric systematic evaluation and genetic studies.

\section{OVERVIEW OF SECONDARY AND SYNDROMIC CRANIOSYNOSTOSIS}

Secondary craniosynostosis results from a known underlying disorder, which can include systemic and metabolic conditions such as hyperthyroidism, hypercalcemia, hypophosphatasia, vitamin D deficiency, renal osteodystrophy, Hurler's Syndrome, sickle cell disease, thalassemia, and encephalocele ${ }^{10,19)}$. Secondary craniosynostosis also develops in cases with post-ventriculoperitoneal shunt and microcephaly due to developmental failure of the brain. Syndromic craniosynostosis is suspected when a patient has psychomotor retardation, digital anomalies, skeletal defects, cardiac defect, or other organ anomalies; most are caused by genetic variants. To date, various causal genes and over 180 syndromes have been reported ${ }^{15)}$.

Secondary or syndromic craniosynostosis needs a more systematic approach. It is important not only to distinguish craniosynostosis from positional skull dysmorphism but also to evalu-

- Received : January 22, 2016 • Revised : February 12, 2016 • Accepted : February 13, 2016

- Address for reprints : Sung Kyoo Hwang, M.D.

Department of Neurosurgery, Kyungpook National University Hospital, 130 Dongdeok-ro, Jung-gu, Daegu 41944, Korea

Tel : +82-53-200-5654, Fax : +82-53-423-0504, E-mail : shwang@knu.ac.kr

- This is an Open Access article distributed under the terms of the Creative Commons Attribution Non-Commercial License (http://creativecommons.org/licenses/by-nc/3.0) which permits unrestricted non-commercial use, distribution, and reproduction in any medium, provided the original work is properly cited. 
ate the cause of the condition. Next-generation sequencing (NGS) technology gives hope to a large number of patients with genetic craniosynostosis by sequencing many candidate genes simultaneously at a reasonable price. In this review, we will focus on the diagnostic evaluation of syndromic craniosynostosis including NGS-based genetic analysis.

\section{SYSTEMATIC EVALUATION OF CRANIOSYNOSTOSIS}

Systematic evaluation includes morphological, imaging, clinical and laboratory tests. Morphological evaluation of the skull should be performed for overall shape and size, and palpation of the anterior and posterior fontanels with attention to size, shape, and fullness with the infant in both the upright and supine positions. In addition to looking at the infant from the front and sides, it is important to observe the skull shape from above, particularly to note any asymmetries in ear position and any flattening of the skull posteriorly, as well as from behind so the levelness of the skull base can be assessed. Deformational plagiocephaly resulting from external molding forces is one of the common causes of cranial asymmetry. Risk factors of positional plagiocephaly are male sex, prematurity, and torticollis. Causes of torticollis include cervical spine abnormality, infection, congenital muscular torticollis, etc. Congenital muscular torticollis can be diagnosed by ultrasonography of the sternocleidomastoid muscle. The most common deformational skull shape is occipital asymmetry. Positional deformation is different from craniosynostosis in that the parallel quadrangular shape results from a positional effect instead of trapezoid shape and compensatory contralateral bulging in craniosynostosis. Occipital flattening is a relatively common feature in oriental neonates and should not be confused with bilateral lambdoid synostosis. The incidence has increased in western countries since the recommendation of putting babies to sleep on their back to prevent sudden infant death syndrome. Sometimes, multiple synostotic patients present with a symmetric, normal-looking appearance. In this case, the skull is small for their age. Close follow up of head circumference and developmental assessment are important in suspected patients. Most cases of craniosynostosis can be diagnosed by their abnormal morphologies and routine radiological examination is not needed. The mainstay of craniosynostosis imaging is three-dimensional CT scan, which facilitates diagnosis of skull fusion in addition to assessment of secondary changes in the cranial fossae, orbits and facial bones. It also enables differentiation of craniosynostosis and positional plagiocephaly. Radioisotope bone scan is helpful; however, it is not used in the clinical setting. Brain magnetic resonance imaging (MRI) is useful for evaluating secondary craniosynostosis due to brain anomalies. If secondary or syndromic craniosynostosis is suspected, further diagnostic procedures are needed. Details of radiologic evaluation will not be discussed in this review. Clinical evaluation is important to assess additional features suggesting a syndrome or complications that need urgent management. Coronal synostosis is the most common type of craniosynostosis associated with other anomalies, suggesting a syndromic nature ${ }^{20)}$. The presence of characteristic facial features and malformations is important for diagnosis of a syndromic craniosynostosis. Special attention should also be paid to the functional consequences of the condition. Decreased level of consciousness, neurologic deficits, breathing difficulty, choking or vomiting on feeds, and irritability may be indications for acute intervention ${ }^{8)}$. Abnormalities of extremities are diagnostic for syndromes; for example, a broad medially deviated thumb or big toe in Pfeiffer syndrome, and more extensive syndactyly in Apert syndrome. Craniosynostosis involving multiple sutures frequently extends to premature fusion of the skull base and shows varying degrees of midfacial underdevelopment, shallow orbit, exophthalmos, low-set ears, narrow, highly arched palate, and malocclusion ${ }^{20)}$. Soft-tissue and skeletal involvement, airway obstruction, dental abnormalities, hearing loss, cardiac anomalies, genitourinary tract anomalies, and gastrointestinal tract anomalies may also be associated and should be assessed in syndromic craniosynosto$\mathrm{sis}^{5,14,19)}$. Laboratory evaluation of thyroid hormone, calcium, phosphate, alkaline phosphatase, and vitamin D levels can serve

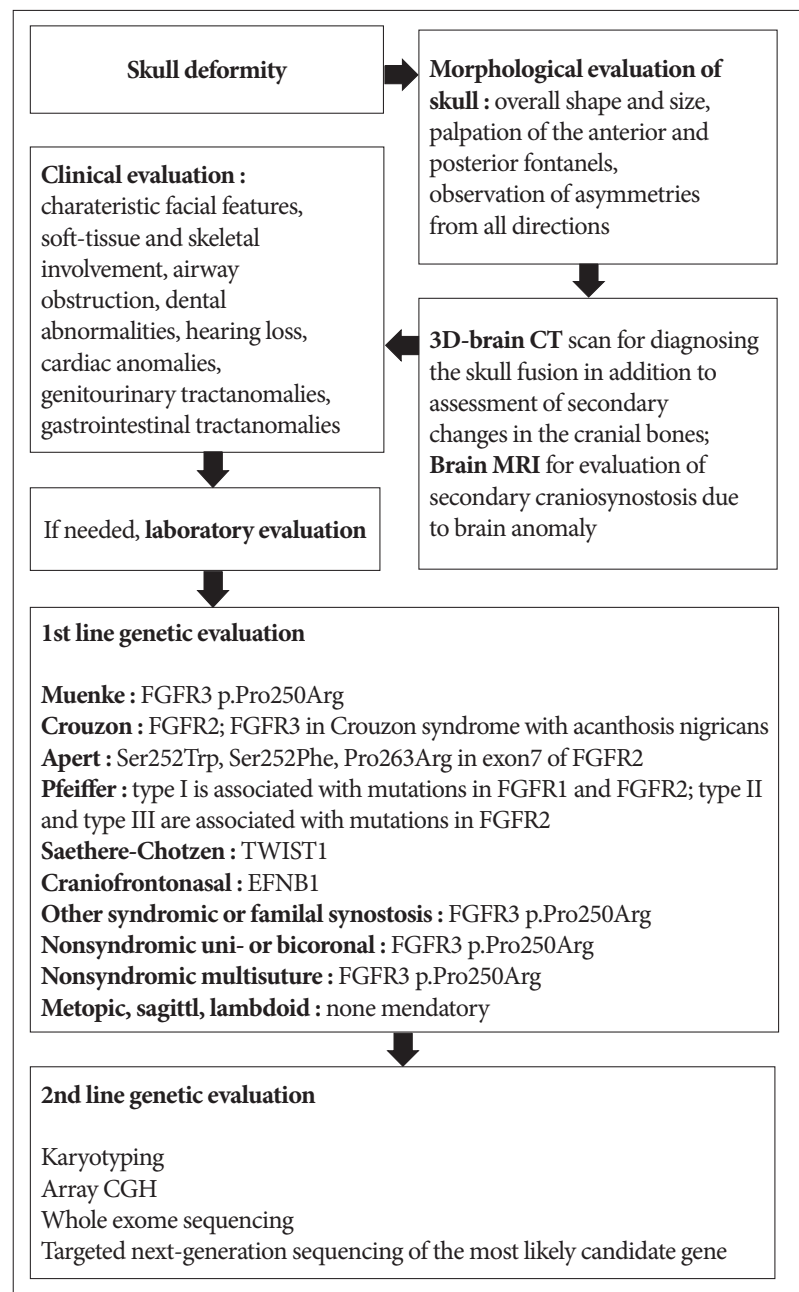

Fig. 1. Flow chart of the clinical and genetic diagnosis of craniosynostosis. 
Table 1. Genetics, epidemiology and characteristic features of known syndromic craniosynostosis

\begin{tabular}{|c|c|c|c|}
\hline Syndrome & Genetics & Epidemiology & Characteristic features \\
\hline Muenke & $\begin{array}{l}\text { - FGFR3 p.Pro250Arg } \\
\text { - Autosomal dominant } \\
\text { disorder }\end{array}$ & $\begin{array}{l}\text { - Incidence : } \\
1 \text { in } 30000 \\
\text { - Most common } \\
\text { craniosynostosis } \\
\text { syndrome } \\
\text { - Approximately } 8 \% \\
\text { of all cases } \\
\text { of craniosynostosis }\end{array}$ & $\begin{array}{l}\text { - Craniosynostosis along the coronal suture } \\
\text { - Sensorineural hearing loss } \\
\text { - Hypertelorism and/or strabismus } \\
\text { - Flattened cheekbones } \\
\text { - About } 5 \text { percent of affected individuals have macrocephaly } \\
\text { - Thimble-like middle phalanges; carpal, and tarsal coalitions; coned } \\
\text { epiphyses } \\
\text { - Approximately one third of individuals have developmental delay or } \\
\text { learning disabilities (usually mild) } \\
\text { - Between } 6 \text { percent and } 7 \text { percent of people with the gene mutation do } \\
\text { not have any of the characteristic features of the disorder }\end{array}$ \\
\hline Crouzon & $\begin{array}{l}\text { - FGFR2 } \\
\text { - FGFR3 in Crouzon } \\
\text { syndrome with } \\
\text { acanthosis nigricans } \\
\text { - Autosomal dominant } \\
\text { disorder with complete } \\
\text { penetrance }\end{array}$ & $\begin{array}{l}\text { - Incidence : } \\
1 \text { in } 60000 \\
\text { - Approximately } 4.8 \% \\
\text { of all cases } \\
\text { of craniosynostosis }\end{array}$ & $\begin{array}{l}\text { - Craniosynostosis involving multiple sutures frequently extend to } \\
\text { - Hyperture fusion of the skull base sutures } \\
\text { - Beaked nose } \\
\text { - Short upper lip } \\
\text { - Midface underdevelopment } \\
\text { - May have orthodontic problems } \\
\text { - May have cleft lip and palate } \\
\text { - Relative mandibular prognathism } \\
\text { - May have occasional upper airway obstruction } \\
\text { - May have conductive hearing loss due to narrow ear canals } \\
\text { - No digital abnormalities are present } \\
\text { - Usually have normal intelligence } \\
\text { - May be accompanied by progressive hydrocephalus }\end{array}$ \\
\hline Apert & $\begin{array}{l}\text { - FGFR2 } \\
\text { - More than } 98 \% \text { of } \\
\text { cases are caused by } \\
\text { Ser252Trp, Ser252Phe, } \\
\text { Pro253Arg in exon7; } \\
\text { the remaining cases are } \\
\text { due to mutations in or } \\
\text { near exon9 of FGFR2 } \\
\text { - Autosomal dominant } \\
\text { disorder; most cases } \\
\text { arise by sporadic } \\
\text { mutation }\end{array}$ & $\begin{array}{l}\text { - Incidence : } \\
1 \text { in } 65000 \\
\text { - Approximately } 4.5 \% \\
\text { of all cases } \\
\text { of craniosynostosis }\end{array}$ & $\begin{array}{l}\text { - Craniosynostosis involving multiple sutures } \\
\text { - Midface underdevelopment with retrusion } \\
\text { - Down-slanting palpebral fissures } \\
\text { - Hypertelorism, exophthalmos, and/or strabismus } \\
\text { - Markedly depressed nasal bridge; short and wide with a bulbous tip; } \\
\text { parrot-beaked appearance; choanal stenosis or atresia } \\
\text { - Down-turned corners of mouth } \\
\text { - High arched palate, bifid uvula, and cleft palate } \\
\text { - Orthodontic problems } \\
\text { - Prominent mandible } \\
\text { - Symmetric complex syndactyly of hands and feet } \\
\text { - Low-set ears with occasional conductive hearing loss } \\
\text { - Other skeletal and cartilaginous segmentation defects including cervical } \\
\text { spinal fusion } \\
\text { - Some of individuals have cardiovascular, genitourinary, gastrointestinal, } \\
\text { or respiratory tract anomalies } \\
\text { - Varying degrees of mental retardation }\end{array}$ \\
\hline Pfeiffer & $\begin{array}{l}\text { - FGFR1 \& FGFR2 } \\
\text { - Pfeiffer syndrome } \\
\text { type I is associated } \\
\text { with mutations in } \\
\text { FGFR1 and FGFR2; } \\
\text { Pfeiffer syndrome type } \\
\text { II and type III are } \\
\text { associated with } \\
\text { mutations in FGFR2 } \\
\text { - Autosomal dominant } \\
\text { disorder } \\
\text { - Essentially, all cases } \\
\text { of Pfeiffer syndrome } \\
\text { type II and type III are } \\
\text { sporadic mutation }\end{array}$ & $\begin{array}{l}\text { - Incidence: } \\
1 \text { in } 100000\end{array}$ & $\begin{array}{l}\text { - Craniosynostosis involving multiple sutures } \\
\text { - Three forms of Pfeiffer syndrome are recognized, of which types II and } \\
\text { III are the more serious } \\
\text { - Type II is characterized by a more severe form of craniosynostosis } \\
\text { (Cloverleaf skull), with more severe hand and foot anomalies } \\
\text { - Type III is similar to type II, with the exception of the cloverleaf skull } \\
\text { deformity } \\
\text { - Hypertelorism, exophthalmos, and/or strabismus } \\
\text { - High forehead } \\
\text { - Midface underdevelopment } \\
\text { - Beaked nose } \\
\text { - Hearing loss (over half of all patients) } \\
\text { - Orthodontic problems } \\
\text { - Upper airway anomalies } \\
\text { - Broad thumbs and great toes } \\
\text { - Medially deviated thumbs and great toes } \\
\text { - Soft tissue syndactyly of fingers and toes } \\
\text { - Brachydactyly } \\
\text { - Varying degrees of mental retardation }\end{array}$ \\
\hline
\end{tabular}


Table 1. Genetics, epidemiology and characteristic features of known syndromic craniosynostosis (Continued)

\begin{tabular}{|c|c|c|c|}
\hline Syndrome & Genetics & Epidemiology & Characteristic features \\
\hline Antley-Bixler & $\begin{array}{l}\text { - Type } 1 \text { is associated } \\
\text { with heterozygous } \\
\text { mutations in FGFR2 } \\
\text { gene; type } 2 \text { is } \\
\text { associated with } \\
\text { homozygous mutations } \\
\text { in the POR gene }\end{array}$ & $\begin{array}{l}\text { - Incidence: } \\
\text { <1 in } 1000000 \\
\text { (>30 patients have } \\
\text { been reported) }\end{array}$ & $\begin{array}{l}\text { - Craniosynostosis of both coronal and lambdoid sutures } \\
\text { - Facial hypoplasia } \\
\text { - Malformations/deformities in most of the skeleton } \\
\text { - Bowed ulna and femur } \\
\text { - Humero-radio-ulnar or radiotrapezoid synostosis } \\
\text { - Synostosis of other bones } \\
\text { - Camptodactyly } \\
\text { - Renal malformations }\end{array}$ \\
\hline Hallermann-Streiff & $\begin{array}{l}\text { - Genetic basis } \\
\text { unknown } \\
\text { - Autosomal recessive } \\
\text { disorder }\end{array}$ & $\begin{array}{l}\text { - Incidence <1 } \\
\text { in } 1000000\end{array}$ & $\begin{array}{l}\text { - Craniofacial malfomations } \\
\text { - Bird-like faces } \\
\text { - Abnormal dentition } \\
\text { - Hypotrichosis } \\
\text { - Atrophy of the skin, congenital cataracts } \\
\text { - Microphthalmia } \\
\text { - Proportionate dwarfism }\end{array}$ \\
\hline Saethre-Chotzen & $\begin{array}{l}\text { - TWIST1 } \\
\text { - Autosomal dominant } \\
\text { disorder }\end{array}$ & $\begin{array}{l}\text { - Incidence: } \\
\quad 1 \text { in 25000-50000 }\end{array}$ & $\begin{array}{l}\text { - Craniosynostosis involving uni- or bilateral coronal sutures } \\
\text { - Ptosis, hypertelorism and/or strabismus } \\
\text { - Down-slanted palpebral fissures } \\
\text { - Midface retrusion } \\
\text { - High arched palate } \\
\text { - Syndactyly of fingers 2-3 } \\
\text { - Brachydactyly } \\
\text { - Small ear pinna without prominent crus } \\
\text { - Duplication of the distal phalanx of the hallux } \\
\text { - Low anterior hairline } \\
\text { - Normal intellect or mild-to-moderate developmental delay }\end{array}$ \\
\hline Craniofrontonasal & $\begin{array}{l}\text {-EFNB1 } \\
\text {-X-linked disorder }\end{array}$ & $\begin{array}{l}\text { - Incidence: } \\
1 \text { in } 120000\end{array}$ & $\begin{array}{l}\text { - Coronal synostosis (brachycephaly/plagiocephaly } \\
\text { - Facial asymmetry (with unicoronal synostosis) } \\
\text { - Hypertelorism with down-slanting palpebral fissures \& broad nasal root } \\
\text { - Grooved nasal tip } \\
\text { - Cleft lip } \pm \text { palate (occasionally) } \\
\text { - Various skeletal anomalies }\end{array}$ \\
\hline
\end{tabular}

as adjuncts to history and examination. A flow chart of clinical and genetic diagnosis of craniosynostosis is shown in Fig. 1.

\section{GENETIC EVALUATION OF CRANIOSYNOSTOSIS}

Molecular genetic evaluation of craniosynostosis is important because the results can provide information about the etiology of the disease and predict the clinical course and prognosis of the patient ${ }^{6}$. About $45 \%$ of unselected cohorts of craniosynostosis patients have a causal genetic alteration detected by current genetic testing strategies ${ }^{6,22)}$. When selecting candidates for molecular genetic testing, various factors-including involved sutures, associated anomalies, developmental milestones, and family history-should be considered. Karyotyping and array comparative genomic hybridization (CGH) are recommended as basic molecular genetic tests for these patients ${ }^{6}$. Various chromosomal aberrations have been associated with syndromic craniosynostosis, and account for at least $10 \%$ of the cases ${ }^{3,4,16)}$. With the increasing availability and use of array CGH, copy number variants (CNVs) such as submicroscopic deletions and duplications have emerged as important causes of craniosynostosis. Mefford et al. ${ }^{12)}$ reported that $7.5 \%$ of individuals with singlesuture synostosis have at least one rare CNV. Trigonocephaly also results from genetic abnormalities, such as deletion of chromosome 9p22-p24 and 11q23 (Jacobsen syndrome) ${ }^{20)}$. Some patients with 22q11.21 microdeletion show craniosynostosis ${ }^{8)}$. Other CNVs-including 1q43, 2p21, 2q14, 3p25, 5p15, 6p21, 6q26, 7q36, 9q21, 11q25, 12p21, and 17q25-have been identified in affected individuals ${ }^{12}$. At the gene level, most abnormalities related to craniosynostosis are FGFR-, TWIST1-, and EFNB1- related syndromes ${ }^{16)}$. The genetics, epidemiology and characteristic features of syndromic craniosynostosis are summarized in Table 1. According to Wilkie et al. ${ }^{22)}$ FGFR2, FGFR3, TWIST1, and EFNB1 account for $25 \%$ of craniosynostosis. Much rarer genetic mutations are in FGFR1 (mild Pfeiffer syndrome), POR (Antley-Bixler syndrome), RAB23 (Carpenter syndrome), EFNA4 (non-syndromic coronal synostosis) ${ }^{13)}$, ESCO2 (Roberts syndrome), GLI3 (Greig syndrome), JAG1 (Alagille syndrome), KRAS (Noonan syndrome), RECQL4 (Baller Gerold syndrome), TGFBR1 or TGFBR2 (Loeys-Dietz syndrome), and MSX2 (single family with supraorbital recession; several duplications have been associated with craniosynostosis) ${ }^{9}$. L1CAM is associated with development of white matter and its mutation can manifest callosal agenesis, mental retardation, adducted thumbs, spasticity, or hydrocephalus ${ }^{15)}$. A defect in the interaction of FGFR with $L 1 C A M$ may be the cause of the brain malformations and 
mental retardation in patients with craniosynostosis ${ }^{17)}$. Genetic consultation based on the result of the evaluation is an important role of the physician responsible for the patient. When family history is negative, a sibling recurrence risk is $2 \%$ for metopic, sagittal and lambdoid synostosis, 5\% for unicoronal synostosis and $10 \%$ for bicoronal and multisuture synostosis ${ }^{8)}$. Genetic evaluation is not mandatory for metopic, sagittal or lambdoid synostosis because the recurrence risk is low and they seldom cause complications. When there is a family history, offspring risks are $\sim 5 \%$ in the case of nonsyndromic sagittal, metopic and unicoronal synostosis; $30-50 \%$ in bicoronal and multisuture synostosis $^{8)}$. Targeted genetic testing should be performed for patients in whom a specific diagnosis is suspected. If a wide range of mutations is found in the suspected causal gene or multiple candidate genes are present, whole-exome sequencing or targeted next-generation sequencing is faster and less costly than Sanger sequencing. Genetic testing for the FGFR3 p.Pro250Arg mutation should be offered for all patients presenting with coronal or multisuture synostosis because it is the most commonly found mutation in all cases of craniosynostosis ${ }^{8)}$. If no genetic abnormalities are identified in the first-line genetic evaluation, the second-line evaluation should include karyotyping and array $\mathrm{CGH}$. Whole-exome sequencing or targeted next-generation sequencing should than be considered if not performed in the first-line genetic evaluation.

\section{CONCLUSION}

Systematic evaluation of the craniosynostosis patient and careful selection of candidates for genetic analysis are important to improve patient outcome by interdisciplinary management of the disease and provision of genetic counseling to the parents.

\section{References}

1. Boulet SL, Rasmussen SA, Honein MA : A population-based study of craniosynostosis in metropolitan Atlanta, 1989-2003. Am J Med Genet A 146A : 984-991, 2008

2. Boyadjiev SA; International Craniosynostosis Consortium : Genetic analysis of non-syndromic craniosynostosis. Orthod Craniofac Res 10 : 129-137, 2007

3. Chinen Y, Kaname T, Yanagi K, Saito N, Naritomi K, Ohta T : Opitz trigonocephaly $\mathrm{C}$ syndrome in a boy with a de novo balanced reciprocal translocation t(3;18)(q13.13;q12.1). Am J Med Genet A 140 : 1655-1657, 2006

4. Eshel G, Lahat E, Reish O, Barr J : Neurodevelopmental and behavioral abnormalities associated with deletion of chromosome 9p. J Child Neurol $17: 50-51,2002$

5. Forbes BJ : Congenital craniofacial anomalies. Curr Opin Ophthalmol
$21: 367-374,2010$

6. Hehr U : Molecular genetic testing of patients with craniosynostosis in Muenke M, Kress W, Collmann H, Solomon BD (eds) : Craniosynostoses : molecular genetics, principles of diagnosis and treatment. Basel : Karger, 2011, Vol 19, pp177-183

7. Hukki J, Saarinen P, Kangasniemi M : Single suture craniosynostosis : diagnosis and imaging in Rice DP (ed) : Craniofacial sutures : development, disease and treatment. Basel : Karger, 2008, Vol 12, pp79-90

8. Johnson D, Wilkie AO : Craniosynostosis. Eur J Hum Genet 19 : 369-376, 2011

9. Kariminejad A, Kariminejad R, Tzschach A, Ullmann R, Ahmed A, Asghari-Roodsari A, et al. : Craniosynostosis in a patient with 2q37.3 deletion 5q34 duplication : association of extra copy of MSX2 with craniosynostosis. Am J Med Genet A 149A : 1544-1549, 2009

10. Khanna PC, Thapa MM, Iyer RS, Prasad SS : Pictorial essay : the many faces of craniosynostosis. Indian J Radiol Imaging 21 : 49-56, 2011

11. Lajeunie E, Le Merrer M, Bonaït-Pellie C, Marchac D, Renier D : Genetic study of nonsyndromic coronal craniosynostosis. Am J Med Genet 55 : 500-504, 1995

12. Mefford HC, Shafer N, Antonacci F, Tsai JM, Park SS, Hing AV, et al. : Copy number variation analysis in single-suture craniosynostosis : multiple rare variants including RUNX2 duplication in two cousins with metopic craniosynostosis. Am J Med Genet A 152A : 2203-2210, 2010

13. Merrill AE, Bochukova EG, Brugger SM, Ishii M, Pilz DT, Wall SA, et al. : Cell mixing at a neural crest-mesoderm boundary and deficient ephrinEph signaling in the pathogenesis of craniosynostosis. Hum Mol Genet 15 : 1319-1328, 2006

14. Panchal J, Uttchin V : Management of craniosynostosis. Plast Reconstr Surg 111 : 2032-2048; quiz 2049, 2003

15. Panigrahi I : Craniosynostosis genetics : the mystery unfolds. Indian J Hum Genet $17: 48-53,2011$

16. Passos-Bueno MR, Fanganiello RD, Jehee FS : Craniosynostosis and chromosomal alterations in Muenke M, Kress W, Collmann H, Solomon $\mathrm{BD}$ (eds) : Craniosynostoses : molecular genetics, principles of diagnosis and treatment. Basel : Karger, 2011, Vol 19, pp152-164

17. Raybaud C, Di Rocco C : Brain malformation in syndromic craniosynostoses, a primary disorder of white matter : a review. Childs Nerv Syst 23 : 1379-1388, 2007

18. Renier D, Sainte-Rose C, Marchac D, Hirsch JF : Intracranial pressure in craniostenosis. J Neurosurg $57:$ 370-377, 1982

19. Robin NH, Falk MJ, Haldeman-Englert CR : FGFR-related craniosynostosis syndromes in Pagon RA, Adam MP, Ardinger HH, Wallace SE, Amemiya A, Bean LJH, et al. (eds) : GeneReviews ${ }^{\circledR}$ [Internet]. Seattle, WA : University of Washington, 1993-2016

20. Sanchez-Lara PA, Graham Jr JM : Congenital anomalies of the skull in Swaiman KF, Ashwal S, Ferriero DM, Schor NF (eds) : Swaiman's pediatric neurology : principles and practice, ed 5. New York : Elsevier Saunders, 2012, pp247-262

21. Thompson DN, Malcolm GP, Jones BM, Harkness WJ, Hayward RD : Intracranial pressure in single-suture craniosynostosis. Pediatr Neurosurg $22: 235-240,1995$

22. Wilkie AO, Bochukova EG, Hansen RM, Taylor IB, Rannan-Eliya SV, Byren JC, et al. : Clinical dividends from the molecular genetic diagnosis of craniosynostosis. Am J Med Genet A 143A : 1941-1949, 2007 